Publisher homepage: www.universepg.com, ISSN: 2663-7529 (Online) \& 2663-7510 (Print)

https://doi.org/10.34104/ejmhs.022.01007

European Journal of Medical and Health Sciences

Journal homepage: www.universepg.com/journal/ejmhs

\title{
A Review of Blastomycosis in Indian Subcontinent
}

\author{
Harish C Gugnani ${ }^{1}$, Anuradha Sharma ${ }^{2}$ and Neelam $\operatorname{Sood}^{3}$ \\ ${ }^{1}$ Dept. of Microbiology (Retired), Vallabhbhai Patel Chest Institute, University of Delhi, Delhi-110007, India; ${ }^{2}$ Dept. of \\ Microbiology, All India Institute of Medical Sciences, Bilaspur (HP), India; ${ }^{3}$ Dept. of Lab Medicine Deen Dayal Upadhyaya \\ Hospital, New Delhi-110058, India. \\ *Correspondence: harish.gugnani@gmail.com (Harish C Gugnani, Professor, Dept. of Microbiology (Retired), Vallabhbhai \\ Patel Chest Institute, University of Delhi, Delhi-110007, India).
}

\begin{abstract}
This study traces earliest cases of blastomycosis reported from India. Four authentic cases of blastomycosis from India including one each from Arunachal Pradesh, Himachal Pradesh, Kerala, and one each from Bangladesh and Nepal, and five misdiagnosed cases have been reported in India after 2013. The clinical and diagnostic features of all cases are reviewed. The authentic cases from India originate from widespread locations in the country. Incidence of blastomycosis in dogs is known to be eight to ten times higher than that in humans. There is only case of canine blastomycosis from India manifesting as fatal pulmonary infection in a Mongrel dog. It is suggested additional canine cases should be looked for in different parts of India to facilitate detection of endemic foci of $B$. dermatitidis for human and animal infections in the country. Mycological investigation of cases of pulmonary tuberculosis negative for culture and AFBs mear, and not responding to anti-tubercular therapy may reveal some cases of blastomycosis. A recently developed real-time PCR for identification of $B$. dermatitidis in culture and tissue may facilitate correct diagnosis of blastomycosis in suspected cases. Antigen testing in urine or serum is also recommended for diagnosing clinical infection and monitoring antifungal therapy in blastomycosis.
\end{abstract}

Keywords: Blastomycosis, Real-time PCR, Indian subcontinent, B. dermatitidis, Status, and Review.

\section{INTRODUCTION:}

Blastomycosis is a systemic mycosis caused by thermally dimorphic fungi, Blastomyces dermatitidis and B. gilchristii. Infection is acquired by inhalation of the organism, followed by its multiplication in the lungs and frequent hematogenous dissemination. Direct inoculation of the fungus is a rare means of infection (Sarcante and Woods, 2010; Benedict et al., 2012). The incubation period varies from 2 to 15 weeks, and the clinical spectrum ranges from asymptomatic to life-threatening infections involving acute respiratory distress syndrome or extra pulmonary dissemination (Sarcante and Woods, 2010) Most identified cases involve pulmonary infection that manifests similarly to other causes of pneumonia (Benedict et al., 2012; Hayle et al., 2020; Schwartz et al., 2018).

The clinical similarities between blastomycosis and other pulmonary infections often result in diagnostic delays and unnecessary empiric antimicrobial drug treatment for suspected bacterial pneumonia (Schwartz et al., 2018). The endemic areas for blastomycosis include states and provinces along Ohio, Mississippi, Missouri, and St. Lawrence River, Canada, Europe, Central America, and India (Sarcante and Woods, 2010; Thompson et al., 2017). 
In reviews of autochthonous cases of blastomycosis from reported from Africa and India (Schwartz et al., 2021; Randhawa et al., 2013), it was found that 100 patients with this disease were reported from 12 African countries, whereas only 10 were described from India. Blastomyces gilchristii is restricted to select Canadian provinces and northern US states, specifically, Alberta, Saskatchewan, British Columbia, Ontario, New York, Minnesota, and Wisconsin (Thompson et al., 2017). Schwartz et al. (2019) described a new species of Blastomyces, Blastomyces helicus, and an emerging pathogen for humans and animals in western Canada and United States. No case of B. gilchristii or B. helicus infection is known from Indian subcontinent.

\section{METHODOLOGY:}

A thorough search of the literature was made on blastomycosis cases reported in countries in the Indian subcontinent in PubMed, MEDLINE, Med Facts using sets of different keywords, viz. India, Bangladesh, Pakistan, Nepal, Bhutan, Sri Lanka, Blastomyces, systemic/deep mycosis, etc. Cross references in the relevant articles were used to download the papers and extract relevant information for incorporation in the review.

\section{RESULTS:}

Literature search revealed that the first report of Blastomyces dermatitidis infection from India was by Ganguli in 1925, described as a very common affliction prevalent in the rainy season, generally affecting t10-40\% coolies working in the tea gardens of Duars situated at the foot of hills in east central Himalayas. From the lesions described as multiple warty ulcerated growths sometimes appearing granuloma to us and the detection of roundy east like cells scraping $\mathrm{s}$ of the lesions described, this report evidences a misdiagnosis of Blastomycosis as these are clinical and histological features of chromo blastomycosis. Again in1925, Panja described a case of generalized Blastomycosis with no dularsk in lesions and yeast-like cells in scrapings. The diagnosis of these two cases is dubious as pointed out in a review by Randhawa et al. (2013).

These authors have reviewed eleven cases of chromoblastomycosis including four authentic cases (including two autochthonous and two imported ones) and seven misdiagnosed ones reported in India up to 2013. The two autochthonous cases comprised one each from Uttar Pradesh and Madhya Pradesh. Our review has located three more authentically diagnosed indigenous cases in India including one each from Arunachal Pradesh (Kumar et al., 2014) Himachal Pradesh (Sharma et al., 2015) and Kerala (Kumar et al., 2019). One authentically diagnosed case each was reported from Bangladesh (Bhuiyan et al., 2015) and Nepal (Gandhi et al., 2015). Also, of five misdiagnosed cases published from India, one each was from Haryana (Rana et al., 2015) and Uttar Pradesh (Shekhar et al., 2016) two from Gujarat (Patel et al., 2014; Hongal \& Geije, 2016) and one from Andhra Pradesh (Rao et al., 2013). The salient clinical features of autochthonous authentic cases of blastomycosis reported from India, Bangladesh and Nepal, and the misdiagnosed ones from India after 2013 are described in Table 1. The state-wise distribution of three Indian authentic indigenous cases of blastomycosis known so far after 2013 in Fig. 1.

\section{Abbreviations}

CNS-Central nervous system, CSF-Cerebrospinal fluid, h/o- History of, $\mathrm{H} \&$ E-Haematoxiin and Eosin, PAS-Periodic Acid-Shiff, GMS-Groctt's methenamine silver, FNAC- Fine needle aspiration cytology, ATTAntitubercular therapy

\section{DISCUSSION:}

The clinical and diagnostic features of the cases reported from India up to 1997 have been described earlier (Randhawa et al., 2013), Though the total number of authentic indigenous cases known form India so far is only six; their locations represent several parts of India, indicating that many more cases of Blastomycosis possibly exist in country but have not been diagnosed. Prolonged blastomycosis results inchronic cough, weightloss, and hemoptysis (Benedict et al., 2012). Pulmonary tuberculosis is quite common in the Indian subcontinent and is often treat dempirically. Mycological investigation of tuberculosis cases, negative for culture and AFBs mear, and not responding to anti-tubercular therapy may reveal some cases of blastomycosis. The areas of environmental distribution of $B$. dermatitidis in India remain undetermined et al. Isolation of $B$. dermatitidia has been reported from the lungs of the bat, Rhino- 
pomahardwickeihardwickei (Khan et al., 1982) and the liver of same bats pieces (Randhawa et al., 1985) in India. It is not known whether bats could be are a reservoir for human infections due to this fungus. In the USA, blastomycosis quite common in dog's residing in or visiting enzootic areas and the incidence of blastomycosis in dogs is eight to ten times higher than that in humans (Schwartz et al., 2018). Most dogs infected by inhaling spores of $B$. dermatitidis from soilor organic debris. Detection of Blastomycosis in dogs is a sentinel of possible occurrence of human cases of this disease (Benedict et al., 2012, Schwartz et al., 2018).

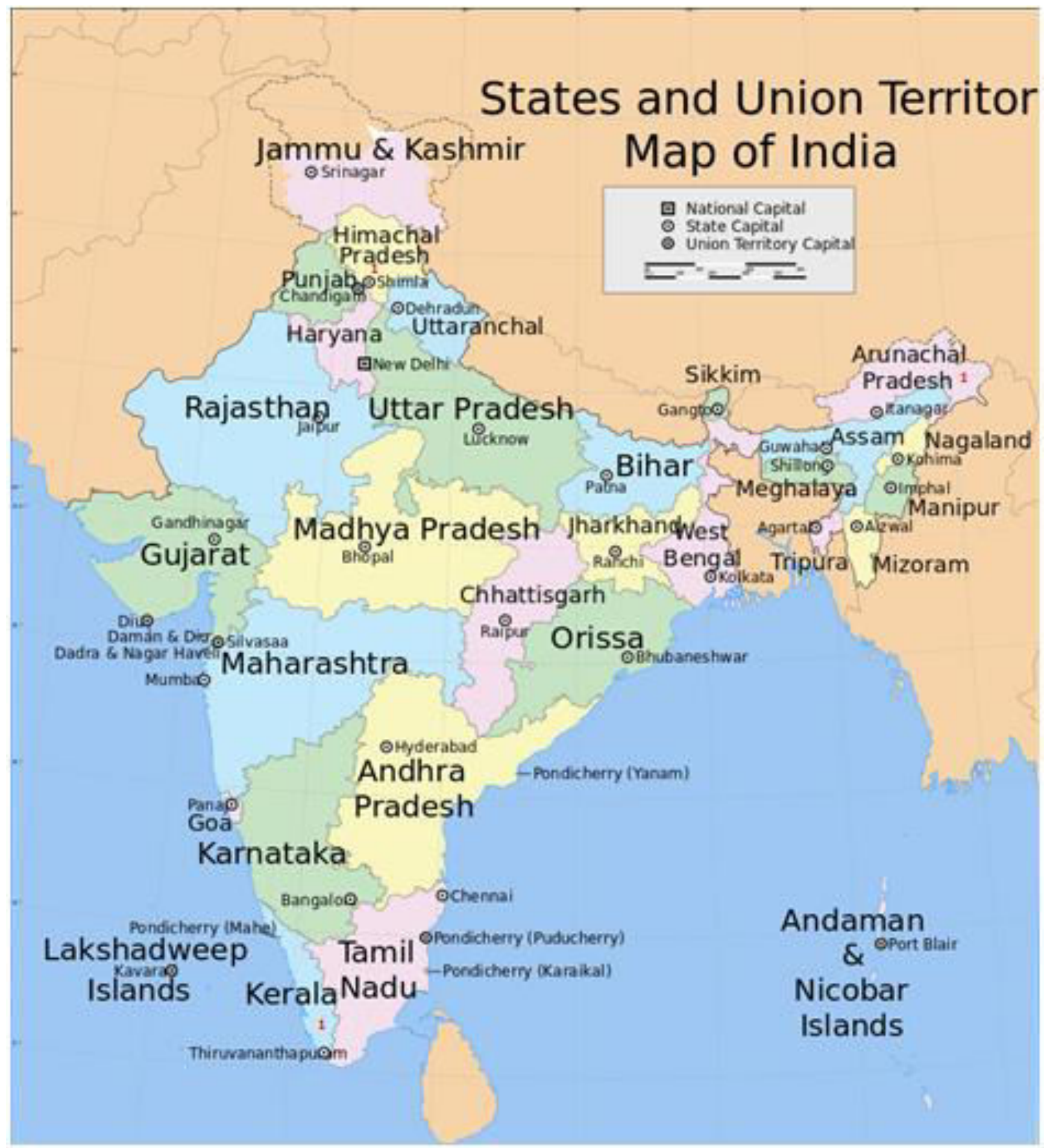

Fig. 1: The state-wise distribution of three Indian authentic indigenous cases of blastomycosis known so far after 2013. 
Table 1: Salient clinical features of all the cases of blastomycosis reported after 2013 from the Indian subcontinent

\begin{tabular}{|c|c|c|c|c|c|}
\hline \begin{tabular}{|c|} 
Serial No \\
Age/Sex
\end{tabular} & Symptoms & Basis of diagnosis & Therapy & Outcome & $\begin{array}{l}\text { Reference/ } \\
\text { Authenticity }\end{array}$ \\
\hline \multicolumn{6}{|c|}{ Cases from India } \\
\hline \begin{tabular}{|c|}
$65 / \mathrm{M}$ \\
Himachal \\
Pradesh
\end{tabular} & $\begin{array}{c}\text { Disseminated } \\
\text { pulmonary infection } \\
\text { with CNS and eye } \\
\text { involvement }\end{array}$ & $\begin{array}{c}\text { Demonstration of broad } \\
\text {-based budding yeast } \\
\text { cells characteristic of } B . \\
\text { dermatitidis in CSF, } \\
\text { sputum, and scrapings } \\
\text { from the nose and soft } \\
\text { palate lesion, } B \text {. Derma- } \\
\text { titid is was also recove- } \\
\text { red in cultures. }\end{array}$ & \begin{tabular}{|c|} 
Intravenous \\
Amphotericn B. \\
The patient \\
developed side \\
reactions of \\
shaking chills and \\
high fever
\end{tabular} & \begin{tabular}{|} 
He developed \\
disseminated \\
intravascular \\
coagulation and left \\
the hospital against \\
medical advice
\end{tabular} & $\begin{array}{c}\text { Sharma et al. }(2015) / \\
\text { Authentic }\end{array}$ \\
\hline $\begin{array}{c}53 / \mathrm{M} \\
\text { Arunachal } \\
\text { Pradesh }\end{array}$ & $\begin{array}{c}\text { Bilateral adrenal } \\
\text { enlargement with mild } \\
\text { cyanosis, clubbing, } \\
\text { fatty hepatomegaly, } \\
\text { mild splenomegaly, h/o } \\
\text { smoking for } 39 \text { yrs. and } \\
\text { diabetes for } 5 \text { yrs. }\end{array}$ & \begin{tabular}{|} 
Demonstration of broad- \\
based yeast cells in PAS \\
and GMS-stained \\
sections of adrenal \\
biopsy, and recovery of \\
B. dermatiitidis in \\
culture of pus obtained \\
by a repeat biopsy
\end{tabular} & \begin{tabular}{|} 
Itraconazole 200 \\
mg twice daily \\
for three months
\end{tabular} & \begin{tabular}{|c|} 
Monthly follow-up \\
showed remarkable \\
improvement with \\
resolution of the \\
lesion after three \\
months as seen in \\
ultrasonography of the \\
abdomen
\end{tabular} & $\begin{array}{c}\text { Kumar et al. (2016)/ } \\
\text { Authentic }\end{array}$ \\
\hline $\begin{array}{r}\text { 32/M } \\
\text { Kerala }\end{array}$ & $\begin{array}{l}\text { Multiple discharging } \\
\text { sinuses on the anterior } \\
\text { chest wall, h/o of travel } \\
\text { to Chicago, USA, and } \\
\text { ATT for } 12 \text { months }\end{array}$ & $\begin{array}{l}\text { Demonstration of } \\
\text { characteristic yeast } \\
\text { forms in PAS and } \\
\text { GMS-stained tissue } \\
\text { sections }\end{array}$ & \begin{tabular}{|} 
Itraconazole 200 \\
mg twice daily \\
for 12 months
\end{tabular} & $\begin{array}{c}\text { The chest wall } \\
\text { sinuses closed, and } \\
\text { the sinus lines } \\
\text { disappeared }\end{array}$ & $\begin{array}{c}\text { Kumar et al. (2019)/ } \\
\text { Authentic }\end{array}$ \\
\hline $\begin{array}{c}\text { 40/M } \\
\text { Haryana }\end{array}$ & $\begin{array}{l}\text { Gross pathology of lung } \\
\text { showed consolidation of } \\
\text { parenchyma with } \\
\text { numerous small. scattered } \\
\text { nodules, Microsection } \\
\text { showed focally } \\
\text { haemorrhagic pneumonia }\end{array}$ & $\begin{array}{c}\text { Demonstration of } \\
\text { rounded to oval yeast } \\
\text { cells with broad-based } \\
\text { doubly contoured yeast } \\
\text { cells with occasional } \\
\text { hyphal forms }\end{array}$ & Fatal case & Not applicable & \begin{tabular}{|c} 
Rana et al. $(2015) /$ \\
Not acceptable, as \\
histology showed \\
yeast cells with \\
hyphal forms, which \\
are not characteristic \\
of $B$. dermatitidis.
\end{tabular} \\
\hline $\begin{array}{c}\text { 12/M } \\
\text { Uttar } \\
\text { Pradesh }\end{array}$ & $\begin{array}{l}\text { Multiple hyperkeratotic } \\
\text { suppurating ulcers of } \\
\text { varying size on the } \\
\text { face, chest and limbs } \\
\text { for } 8 \text { months. Ulcers } \\
\text { were mobile and pus } \\
\text { was draining from some } \\
\text { of the ulcers }\end{array}$ & $\begin{array}{c}\text { Clusters of large, } \\
\text { variably sized, thick- } \\
\text { walled, broad-based, } \\
\text { multiple budding brown } \\
\text { coloured refractile cells } \\
\text { and hyphae like rows of } \\
\text { budding cells seen in H } \\
\text { \& E and PAS-stained } \\
\text { tissue sections }\end{array}$ & \begin{tabular}{|c|} 
Started on oral \\
itraconazole \\
$5 \mathrm{mg} / \mathrm{kg} /$ day. \\
Intravenous (I.V) \\
along with sefo- \\
perezone and \\
sulbactam com- \\
bination was \\
started along with \\
vancomycin \\
$3 \mathrm{mg} / \mathrm{kg} /$ day.
\end{tabular} & \begin{tabular}{|c|} 
His skin lesions \\
improved following \\
which he was give \\
three packed blood \\
transfusions over a \\
period of 7 days. The \\
child became uncons- \\
cious on $4^{\text {th }}$ day and \\
then started on I.V. \\
amphotericin B $5 \mathrm{mg} /$ \\
kg, Unfortunately \\
the child died.
\end{tabular} & $\begin{array}{l}\text { Shekhar et al. }(2016) / \\
\text { Not acceptable, since } \\
\text { the lesions and the } \\
\text { histopathology were } \\
\text { characteristic of } \\
\text { chromo-blasto- } \\
\text { mycosis, rather than } \\
\text { blastomycosis. It was } \\
\text { a very poorly } \\
\text { managed case. }\end{array}$ \\
\hline
\end{tabular}




\begin{tabular}{|c|c|c|c|c|c|}
\hline $\begin{array}{c}\text { 37/M } \\
\text { Gujarat }\end{array}$ & $\begin{array}{l}\text { Multiple small } \\
\text { maculopapular, } \\
\text { firm nodules with } \\
\text { sinuses on the middle } \\
\text { third of the dorsal } \\
\text { aspect of the knee, h/o } \\
\text { renal transplant }\end{array}$ & $\begin{array}{c}\text { Clusters of yeast cells } \\
\text { and presence of IgG } \\
\text { serum antibodies to } \\
\text { B. dermatitidis. Cultures } \\
\text { not successful }\end{array}$ & $\begin{array}{c}\text { Initial treatment } \\
\text { with fluconazole } \\
\text { failed, switched } \\
\text { to Itraconazole } \\
400 \mathrm{mg} \text { daily. } \\
\text { Duration not } \\
\text { mentioned }\end{array}$ & The lesions healed & $\begin{array}{c}\text { Patel } \text { et al. }(2014) / \\
\text { Not acceptable as } \\
\text { examination of the } \\
\text { histology image in the } \\
\text { publication showed } \\
\text { only one budding } \\
\text { yeast cell and a pseu- } \\
\text { dohypa. }\end{array}$ \\
\hline $\begin{array}{c}\text { 35/M } \\
\text { Gujarat }\end{array}$ & $\begin{array}{c}\text { Multiple small } \\
\text { Vegetations over the } \\
\text { upper limbs, lower right } \\
\text { leg, a few ulcers on } \\
\text { right arm and crusted } \\
\text { ulcers over the } \\
\text { mammaryarea. }\end{array}$ & $\begin{array}{l}\text { Diagnosed merely on } \\
\text { appearance of the } \\
\text { clinical lesions. }\end{array}$ & $\begin{array}{c}\text { The lesions star- } \\
\text { ted to heal. The } \\
\text { patient was } \\
\text { given cefaxine } \\
\text { and advised to } \\
\text { stop smoking \& } \\
\text { alcohol } \\
\text { consumption. }\end{array}$ & & \begin{tabular}{|c|} 
Hongal \\
andGeije $(2016) /$ Not \\
acceptable, as clinical \\
lesions are rather \\
suggestive of \\
chromoblasto- \\
mycosis.
\end{tabular} \\
\hline $\begin{array}{c}\text { 4/M } \\
\text { Andhra } \\
\text { Pradesh }\end{array}$ & $\begin{array}{l}\text { Multiple hyperkeratotic, } \\
\text { verrucose, suppurating } \\
\text { plaques and nodules over } \\
\text { the face, chest back and } \\
\text { multiple umbilicated } \\
\text { papules and nodules on } \\
\text { extremities and a huge } \\
\text { intraocular flesh-coloured } \\
\text { mass in the left eye. } \\
\text { FNAC of the cervical } \\
\text { lymph nodes showed non- } \\
\text { specific lymphadenitis. }\end{array}$ & $\begin{array}{c}\text { Clinical lesions not } \\
\text { suggestive. Illustrations } \\
\text { indicating B. } \\
\text { dermatitidis in tissue } \\
\text { sections not provided. }\end{array}$ & . & & \begin{tabular}{|c|} 
Rao et al. $(2014) /$ \\
Not accepted since \\
clinical lesions are \\
not suggestive of \\
blastomycosis and no \\
illustration of yeast \\
cells $B$. dermatitidis \\
was provided. \\
There was also poorly \\
managed case.
\end{tabular} \\
\hline \multicolumn{6}{|c|}{ Cases from Bangladesh } \\
\hline \begin{tabular}{|c|} 
40/M \\
Dhaka
\end{tabular} & $\begin{array}{l}\text { Single, well } \\
\text { demarcated, oval } \\
\text { plaque with a few } \\
\text { crusts on the lower } \\
\text { part of chest wall }\end{array}$ & \begin{tabular}{|c|} 
Demonstration of \\
characteristic yeast form \\
in $\mathrm{KOH}$ preparation of \\
biopsy
\end{tabular} & $\begin{array}{c}\text { Itraconazole } 200 \\
\text { mg daily for three } \\
\text { months }\end{array}$ & Cured & $\begin{array}{c}\text { Bhuiyan et al. (2015) } \\
\text { /Authentic }\end{array}$ \\
\hline \multicolumn{6}{|c|}{ Cases from Nepal } \\
\hline \begin{tabular}{|c|}
$60 / \mathrm{F}$ \\
imported \\
case $(\mathrm{a}$ \\
Nepalese \\
immigrant \\
in USA)
\end{tabular} & $\begin{array}{l}\text { Pulmonary infection, } \\
\text { multi-lobular } \\
\text { consolidation and foci } \\
\text { of necrosis in the lung, } \\
\text { followed by a necrotic } \\
\text { ulcer on the dorsum of } \\
\text { the tongue, h/o } \\
\text { Coombs- positive } \\
\text { autoimmune } \\
\text { hemolyticanemia, and } \\
\text { diabetes mellites. Case } \\
\text { diagnosed in USA } \\
\text { after the patients } 9 \\
\text { months stay in Nepal. }\end{array}$ & \begin{tabular}{|c|} 
Broad-based budding \\
yeast cells in PAS and \\
GMS- stained tissue \\
sections of a \\
transbronchial biopsy and \\
recovery of $B$. \\
dermatitidis from tongue \\
ulcer, BAL fluid and \\
bronchoscopic biopsy
\end{tabular} & $\begin{array}{c}\text { Oral itraconazole } \\
\text { for } 12 \text { months }\end{array}$ & Cured. & $\begin{array}{c}\text { Gandhi et al. } 2015 \text { / } \\
\text { Authentic }\end{array}$ \\
\hline
\end{tabular}




\section{CONCLUSION:}

Blastomycosis primarily acanine disease and occurs in dogs about ten times more in humans than that in dogs The review by Randhawa et al. (2013 mentioned only one case of can in blastomycosis from India, manifesting as pulmonary infection in a Mongrel dog found dead in Bareli, Uttar Pradesh. Human cases of blastomycosis covered in our review originated from several distant locations in India, Blastomycosis is primarily a canine disease (Schwartz et al., 2018) Surveillance for more canine cases in several parts of India and other countries in the Indian subcontinent may facilitate detection of endemic foci of $B$. dermatitidis for human and animal infections. Possibly many more human cases of blastomycosis exist that have not been recognized. A recently developed real-time PCR for identification of $B$. dermatitidis in culture and tissue and antigen testing in broncho-alveolar fluid (Bal), serum and urine is also useful for diagnosis of Blastomycosis (Sidamonidze et al., 2012; Linder et al.,2021)

\section{ACKNOWLEDGEMENT:}

The author is incredibly grateful to MS Sonia SardanaGugnani of American Express for constructing Fig. 1.

\section{CONFLICTS OF INTEREST:}

We have no conflict of interest in this research.

\section{REFERENCES:}

1) Benedict E, Roy MT, Chiller T, Davis JP, (2012). Epidemiological and ecological features of blastomycosis: a review. Curr Fungal Infect Rep, 6(4), 327-35. https://doi.org/10.1007.12281-012-110-1

2) Bhuiyan I, Hossain M, Akhtar M, (2015). Cutaneous blastomycosis: A rare case. Northern Int Med College J, 8(1), 189-191.

3) Gandhi V, Singh A, Woods GL, Epelbaum O A, (2015). 66-yearl old woman with fever, cough and a tongue lesion. Chest, 147(4), e140-e47. https://doi.org/10.1378/chest 14-1858

4) Hayle WA, Ahmed R, and Uddin ME. (2020). Prevalence of subclinical mastitis among small ruminants and isolation of some bacterial pathogens in Jimma Town, Ethiopia, Eur. J. Med. Health Sci., 2(6), 107-124. https://doi.org/10.34104/ejmhs.020.01070124
5) Hongal, AA, Gejje S, (2016). Blastomycosis-like pyoderma: A rare case report, J Clin Diagnostic Res, 10(1), pp. WD03 - WD04. https://doi.org/10.7860/JCDR/2016/20468.8610

6) Khan ZU, Randhawa HS, Lulla ML, (1982). Isolation of Blastomyces dermatitidis from the lungs of bat Rhinopomahardwickeihardwickei Gray in Delhi. Sabouraudia, 20(4), 137-144.

7) Kumar A, Kunoor A, Eapen M, Singh PK, Chowdhary A, (2019). Blastomycosis misdiagnosed as tuberculosis, India. Emer Infect Dis, 25(9), 1776-1777. https://doi.org/10.3201/eid2509.190587

8) Kumar A, Sreehari S, Velyaudhan K Biswas L, Babu R, Ahmad S, (2014). Autochthonous blastomycosis of the adrenal: First case report from Asia. Am J Trop Med Hyg, 90(4), 735-739.

9) Linder AK, Kaufman CA, (2021).Current and new perspectives in the diagnosis and management of blastomycosis and histoplasmosis. $J$ Fungi, 7(1), pp. 12. https://doi.org/10.3390/jof7010012

10) Patel HJ, Kute V, Vanikar AV, Shah P, Gumber MR, Trivedi H, (2014). Blastomyces dermatitidis in renal transplant recipient. Saudi $J$ Kidney Dis Transplant, 25(5), 1042-1045.

11) Rana S, Sharma P, Satarkar RN, Kalhan S, Garg S, (2015). Pulmonary blastomycosis on autopsy: a rare case report. Int J Res Med Sci, 5(3), pp. 498-501.

https://doi.org/10.5455/2320-6012.ijrms201550223

12) Randhawa HS, Chowdhary A, Kathuria S, Roy P, Misra Jain SS, Chugh TD, (2013). Blastomycosis in India: a case report and current status Med Myco, l6, 185-191. https://doi.org/103109/1369386.2012.686960

13) Randhawa HS, Chaturvedi VP, Kini S, Khan. $\mathrm{ZU}$, (1985). Blastomyces dermatitidis in bats. First report of its isolation from the liver of Rhinopomahardwickei Gray. Sabouraudia, 23(1), pp. 69-76.

14) Rao GR, Narayan BL, Durga Prasad BK, Amareswar A, Sridevi M, Raju B, (2013). Disseminated blastomycosis in a child with a brief review of the Indian literature. Indian J Dermatol Venereol Leprol, 7, 92-6. https://doi.org/10.4103/0378-6323.104676 
15) Saccente M, Woods GC, (2010). Clinical and laboratory update on blastomycosis. Clin Microbial Rev, 23(2), pp. 361-383. https://doi.org/10.1128/CMR.00056-09

16) Schwartz IS, (2018). Blastomycosis in Mammals. In: Seyedmousavi S., de Hoog G., Guillot J., Verweij P. (eds) Emerging and Epizootic Fungal Infections in Animals. Springer, Cham. https://doi.org/10.1007/978-3-319-72093-7_8

17) Schwartz IS, Mudoz JE, Kenyon CR, Govender NP, Taggart LM, Maphanga TG et al. (2021). Blastomycosis in Africa and the Middle East: A comprehensive review of reported cases and analysis of historical isolates basd on molecular data. Clin Infect Dis, 73(7), e1560-1569. https://doi.org/10.1093/cid/ciaa/1100

18) Schwartz IS, Widerhold NP, Hanson KE, Patterson TE, Sigler L, (2019). Blastomyces helicus, a new dimorphic fungus causing fatal pulmonary and systemic disease in humans and animals in Western Canada and the United States. Clin Infect Dis, 68(2), 188-195. https://doi.org/10.1093/cid/ciy483
19) Seyedmousavi S, de Hoog G, Guillot J, Verwei P, (2018). Schwartz IS Blastomycosis in Mammals. Emerging and epizootic fungal infections in animals, Springer, Cham, ISBN: 978-3-31972093-7.

https://doi.org/10.1007/978-3-319-72093-78

20) Sharma A, Singh D, Gupta M, (2015). Blastomycosis from a local farmer in Himachal Pradesh, North India: A diagnostic dilemma, ISOR J Dent Med Sciences, 14(8), 86-89.

21) Shekhar A, Gahalaut PK, Mishra PN, (2016). A rare fatal case of disseminated cutaneous blastomycosis in a child. Indian J Paediatr Dermatol, 7, 300-302.

22) Sidamonidze K, Peck MK, Perez M, Bamgardner D, Smith G, Chaturvedi V, (2012). Real-time PCR for identification of Blastomyces dermatitidis in culture and tissue. J Clin Microbiol, 50(5), 1783-1786. https://doi.org/11.1128/JCM0031

23) Thompson K, Sterkel AK, Brooks EG, (2017). Blastomycosis in Wisconsin: Beyond the outbreaks. Acad Forensic Pathol, 6(1), 119-129. https://doi.org/10.239072017.014

Citation: Gugnani HC, Sharma A, and Sood N. (2022). A review of Blastomycosis in Indian subcontinent. Eur. J. Med. Health Sci., 4(1), 01-07. https://doi.org/10.34104/ejmhs.022.01007 @) 